Ks. Wojciech Pikor

Verbum Vitae 28 (2015) 155-180

\title{
IZRAEL JAKO ŚWIADEK BOGA (IZ 43,8-13)
}

Israel as God's Witness (Isa 43:8-13)

Abstract: The subject of our analysis is an extract from the Book of Isaiah, 43:8-13, which represents a significant moment in a bilateral controversy ( $r \hat{i} b$ ) ordered by Yahveh against foreign nations and the gods they worship. The juridical controversy decides about powerful and dynamic narration in Deutero-Isaiah. There is an unexpected twist of action as the legal proceeding unfolds: Israel, once God's witness, now becomes a nation accused of rejecting its primary vocation of being a witness. Our quest for the reasons behind Israel's failed testimony to God hinges on decoding the idealized content of that testimony. God does not renounce his revelation to the world but makes Yahveh's Servant his witness. The Servant will not only lead the world to the truth about God but also justify Israel, as well as other nations, by forming a covenant with the people.

Keywords: Book of Isaiah, Yahveh's Servant, covenant, testimony, monotheism, rîb, juridical controversy

Streszczenie: Przedmiotem analizy jest tekst Iz 43,8-13. Jest to ważny moment w procesie sądowym, który Jahwe prowadzi z obcymi narodami i czczonymi przez nich bogami. Proces stanowi o dynamice narracyjnej Deutero-Izjasza. Dochodzi do zwrotu akcji w toczącym się procesie - Izrael z pozycji świadka Jahwe sam staje się oskarżony o odrzucenie powołania do bycia świadkiem. Poszukiwanie przyczyn nieudanego świadectwa 
Izraela o Bogu łączy się z odczytaniem treści tego świadectwa. Bóg nie rezygnuje $z$ objawienia się światu i swoim świadkiem czyni postać nazwaną Sługą Jahwe, który nie tylko doprowadzi świat do poznania prawdy o Bogu, ale również usprawiedliwi Izrael i inne narody, stając się, ,przymierzem ludu”.

Słowa kluczowe: Księga Izajasza, Izajasz, Sługa Jahwe, przymierze, świadectwo, monoteizm, rîb, kontrowersja jurydyczna, spór prawny

Nie ma w Biblii Hebrajskiej drugiego takiego tekstu jak Iz 43,8-13, w którym zostałoby tak dobitnie i z detalami opisane powołanie Izraela do bycia świadkiem Boga. Zauważa to Paul Ricoeur, który ten właśnie tekst prorocki - wraz z Ewangelią Janową - wykorzystuje w refleksji nad „hermeneutyką świadectwa” w jej podwójnym wymiarze: świadectwa jako wyznania wiary oraz świadectwa jako opowiadania o faktach ${ }^{1}$. Proponowana przez niego analiza Iz 43,8-13 pod kątem, ,semantycznej przeróbki świeckiego sensu" świadectwa sprowadza się do określenia czterech elementów kluczowych - jego zdaniem - dla fenomenu świadectwa: posłania świadka (aby zaświadczył), przedmiotu świadectwa (nie chodzi o odosobnione i przypadkowe fakty, lecz o całościowy sens ludzkiego doświadczenia), jego celu (jest nim głoszenie, rozpowszechnienie, szerzenie) i sposobu świadczenia (nie tylko słowami, ale i czynami). Proponowane przez Ricoeura ujęcie bez wątpienia oddaje strukturę świadectwa jako takiego, jednakże nie do końca odpowiada rzeczywistości opisanej przez proroka. Francuski filozof pomija przede wszystkim fakt, iż Izrael, mimo bycia wezwanym przez Boga na swojego świadka, tego świadectwa nie podją. Pewnym uproszczeniem jest również twierdzenie, że ,świadectwo jest ukierunkowane na głoszenie" w tym sensie, że ,pewien lud jest świadkiem dla wszystkich narodów"2. Otwartą kwestią pozostaje również sposób dania świadectwa przez Izrael - Ricoeur mówi

${ }^{1}$ Ricoeur, „Hermeneutyka świadectwa”, 15-46. Tekst Iz 43,8-13 przywołany na s. 26-27.

2 Ricoeur, „Hermeneutyka świadectwa”, 27. 
o ,zaangażowaniu nie tylko w słowach, lecz w czynach i, ostatecznie, w ofierze życia". Gdzie jednak szukać potwierdzenia tej opinii w Iz 43,8-13? Bez wątpienia intuicja Ricoeura co do znaczenia Iz 43,8-13 w budowaniu ,filozofii świadectwa" jest słuszna, wymaga ona jednak - jak jest to postulowane przez samego Ricoeura - egzegezy biblijnej, która podprowadzi pod ,egzegezę refleksyjnej świadomości siebie" 3 . Przyjmując zatem podejście synchroniczne do proroctwa Deutero-Izajasza, fenomen świadectwa, do którego jest wezwany Izrael, zostanie opisany w następującym porządku: najpierw kontekst (literacki i historyczny) tego świadectwa, co pozwoli na postawienie pytania o jego cel; następnie przedmiot tego świadectwa; dalej przeszkody na drodze dawania świadectwa, co ostatecznie doprowadzi do pytania o los świadectwa w sytuacji, gdy powołany na świadka Izrael zawiódł.

\section{Kontekst ŚWIADECTWA}

Wśród komentatorów panuje przekonanie, iż Księga Deutero-Izajasza wydaje się kolekcją krótkich wyroczni, istniejących pierwotnie samodzielnie, różniących się między sobą gatunkiem literackim, realizujących odmienne cele komunikacyjne ${ }^{4}$. Wyrocznia Iz 43,8-13 nie stanowi do końca tekstu oryginalnego, gdyż swoim gatunkiem literackim nawiązuje do innych tekstów z Iz 40-55, w których mowa jest o dyspucie sądowej Jahwe $\mathrm{z}$ obcymi narodami lub z ich bóstwami: 41,1-5.21-29; 44,6-8; 45,20-225 . Elementy wspólne pozwalają na odtworzenie następującego przebiegu dysputy:

a) wezwanie uczestników procesu (por. czasownik qārab [,,zbliżyć się"] w 41,1.5.21, nāḡaš [,,zbliżyć sięe”] w 41,1.22; 45,20.21, qāṣab [,,zgromadzić się"] w 43,9;

\footnotetext{
${ }^{3}$ Ricoeur, ,Hermeneutyka świadectwa”, 37.

${ }^{4}$ Por. Gołębiewski, „Wizja odnowy Izraela”, 17.

${ }^{5}$ Por. Simian-Yofre, Sofferenza dell'uomo e silenzio di Dio, 169-171.
} 
45,20, 'āsā̄ [,zgromadzić się"] w 43,9; brak tego rodzaju czasowników w 44,6-8); ich identyfikacja jako "narody" $(41,1)$, ich bóstwa (por. 41,23), „ludy” i ,narody” $(43,9)$, „ocaleni z narodów” $(45,20)$;

b) dysputa z pytaniem retorycznym Jahwe, który rzuca wyzwanie swoim adwersarzom: pytajnik „kto" (mî) łączący się z czasownikami: "ûr (,,wzbudzić”) w 41, 2; pācal (,uczynić”) w 41,4; nāgad (,oznajmić”) w 41,26; 43,9; 44,7; 45,21; šāma' (,dać usłyszeć”) w 43,9; 45,21;

c) wyrok w postaci negatywnej odpowiedzi Jayin (,nikt”) samego Jahwe na pytanie retoryczne - brakuje jej w 41,1-5; w 41,21-29 występuje siedem, w 43,8-13 trzy, w 44,6-8 dwa, w 45,20-22 trzy razy. Towarzyszy jej odpowiedź pozytywna, która zawiera się w stwierdzeniu: ’ănî yhwh (41,4; 45,21), ’ānōkî yhwh (43,11), ’ănî '’̄l $(43,12 ; 45,22)$, ’ănî-hû̀ $(41,4 ; 43,10.13)$, lub w pytaniu retorycznym: „kto jest jak Ja” (mî́-kāmônî w 44,7).

W świetle powyższego zestawienia elementów formalnych stanowiących o gatunku dysputy sądowej w Iz 43,8-13 należy zauważyć kilka elementów, które sytuują tę wyrocznię w szerszym kontekście narracyjnym.

Ȧż trzykrotnie są wzmiankowani ,świadkowie": z jednej strony w w. 9 Jahwe wzywa bóstwa do ,przedstawienia swoich świadków" (yittonû 'êdêhem), z drugiej zaś strony w ww. 10.12 zwraca się do Izraela, wzywając go na swojego świadka: „wy jesteście moimi świadkami” ( 'attem 'ēday). Ta sama formuła wezwania Izraela na świadka powróci w 44,8. Bóg zatem rzuca wyzwanie bóstwom obcych narodów, co każe przywołać dwie wcześniejsze dysputy w 41,1-5.21-29, stanowiące o rozwoju narracji w Iz 40-55'. W rozdz. 41 Jahwe wzywa na sąd swoich oponentów: są nimi obce narody $(41,1)$ wraz z ich bóstwami (41,21-23). Przedmiotem sporu jest zdolność Jahwe lub bóstw do objawienia historii i urzeczywistnienia jej. Dysputa $\mathrm{z}$ rozdz. 43 stanowi o kontynuacji tego procesu, w którym strony procesujące się mają dostarczyć własnych

${ }^{6}$ Szerzej o strukturze narracyjnej Deutero-Izajasza w: Pikor, Soteriologiczna metafora wody, 245-247. 
świadków potwierdzających prawdę słów wypowiadanych przez bóstwa (por. oczekiwaną płonnie w w. 9 deklarację: „To prawda" [ ’’̌met]). Ze strony bóstw pogańskich jest to niemożliwe, gdyż nie są one w stanie obwieszczać i interpretować przeszłych i przyszłych zdarzeń $(41,23)$. Skoro „nikt nie objawił i nikt nie obwieszczał”, jest zrozumiałe, że „nikt nie słyszał słów waszych”, bo ich po prostu nie mogło być $(41,26)$. Jeśli zatem dysputa zapisana w Iz 41 kończy się wykazaniem, iż bóstwa obcych narodów nie istnieją, dlaczego wzywani są świadkowie?

Mimo że w Iz 41,1 pojawia się termin mišpāt na określenie sądu, to z kontekstu wynika, że nie chodzi o proces sądowy (z udziałem stron, oskarżyciela, obrońcy, sędziego), lecz o procedurę sporu sądowego, co potwierdza wystąpienie terminu $r \hat{b} \underline{b}$ w 41,21 (por. 41,11). Na gruncie sądowym spotykają się dwie strony, z których jedna naruszała prawa drugiej. Strona pokrzywdzona oskarża drugą stronę o niesprawiedliwość lub niewierność we wzajemnej relacji, domagając się uznania swojej racji i przywrócenia relacji respektującej prawo ${ }^{7}$. Jeśli nie dojdzie do pojednania stron, wówczas sprawa trafia przed trybunał sądowy. W kontekście sporu zainicjowanego w Iz 41 należy postawić pytanie o przyczynę tej kontrowersji. Impulsem do niego jest skarga, jaką Izrael podnosi w 40,27: „Zakryta jest moja droga przed Jahwe i moje prawo (mišpătîn) przez Boga pominięte". W przekonaniu Izraelitów wygnanie babilońskie miałoby dowodzić, że Jahwe o nich zapomniał, a nawet ich odtrącił. Kontestacja Boga ze strony Izraela idzie jednak dalej, na co wskazują słowa, którymi prorok odrzuca ich skargę: naród wybrany podejrzewa Jahwe o słabość, skoro Babilończycy, a wraz z nimi ich bóstwa, odniosły triumf nad ludem będącym własnością Jahwe (por. 40,28-31). Na skargę Izraelitów Bóg odpowiada sporem, w który wchodzi z obcymi narodami i czczonymi przez nich bóstwami. Świadkami są tradycyjnie elementy natury, które - stworzone przez Boga - od początku istnienia świata asystują Jego działaniu w historii (w 41,1 są

${ }^{7}$ Por. Bovati, Ristabilire la giustizia, 21-26. 
nimi ,wyspy") ${ }^{8}$. Izrael w tej fazie sporu jest nieobecny, jakkolwiek, mając na uwadze, że Jahwe działa ze względu na jego skargę, lud wybrany jest beneficjentem tego sporu. Sytuacja zmienia się w rozdz. 43, kiedy to Jahwe wzywa na swojego świadka Izrael. Logika tego wezwania jest podwójna.

Po pierwsze, świadkiem może być osoba, która ma znajomość faktów stanowiących przedmiot procesu. Jednakże to nie wystarczy - konieczne jest słowo, za pomocą którego świadek objawi te fakty w toczącym się proce$\operatorname{sie}^{9}$. Z tego powodu świadectwo elementów wszechświata pozostaje niewystarczające, gdyż mimo znajomości faktów potwierdzających zaangażowanie się Jahwe w historię Izraela nie są one w stanie złożyć zwerbalizowanego świadectwa. Stąd potrzeba świadka, który umie mówić.

Po drugie, formuła wezwania na świadka w 43,10.12 przynosi odwrócony porządek stanowiących ją elementów. Normalnie w formule ustanawiającej kogoś świadkiem jego imię lub określenie jest poprzedzone rzeczownikiem „świadek": 'ēdîm 'attem (Joz 24,22; Rt 4,9.10); 'ē $\underline{d} h \hat{u}^{\text {' }}$

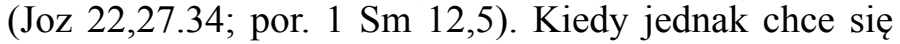
wyeksponować to, kim jest świadek, wówczas formuła przynosi odwrócony układ, właśnie taki jak w Iz 43,10.12: attem 'e $\underline{d} a y^{10}$. Do tego dochodzi niespotykane w procedurze wezwania na świadka wzmocnienie tej formuły wyrażeniem nə’um-yhwh, które jest właściwe - jako formuła konkluzyjna - wyroczni prorockiej. W ten sposób Jahwe podkreśla niepowtarzalną jakość Izraela jako swojego świadka, który był pierwszym beneficjentem Jego zbawczego działania w historii. Problem w tym, że Izrael nie rozpoznaje tego działania Boga w świecie, czego wyrazem jest obecna w 40,27 skarga, iż Bóg nie troszczy się o nie-

${ }^{8}$ Najpełniej ten element $r i ̂ b$ prorockiego zauważa się w Mi 6,1-2, gdzie na świadków sporu Jahwe ze swoim ludem zostają przywołane „góry”, ,pagórki” i ,posady ziemi”.

${ }^{9}$ Por. Bovati, Ristabilire la giustizia, 240.

${ }^{10}$ Simian-Yofre, Sofferenza dell'uomo e silenzio di Dio, 178. 
go. W rezultacie staje się konieczne przekonanie ludu do tego, by podjął się roli świadka ${ }^{11}$.

Cel świadectwa, do którego jest wezwany Izrael, okazuje się paradoksalny w kontekście procedur sądowniczych. Rzadko bowiem rzeczownik jest łączony z sufiksem. Gdy ta sytuacja ma miejsce - tak jak w Iz 43,10.12 (por. 44,8) - wiadomo, że chodzi o świadka obrony ${ }^{12}$. Jednakże Jahwe nie potrzebuje obrońcy, gdyż już wcześniej okazało się, że to, co obce narody nazywają „bogami”, nie jest w stanie „,powiedzieć, co ma nadejść” ani też ,zrobić coś dobrego lub uczynić coś złego" (Iz 41,23). W świadectwie, do którego jest wezwany Izrael, nie chodzi zatem na pierwszym miejscu o narody z ich bożkami, lecz o sam Izrael, który musi jako świadek dojść do poznania i wiary w Jahwe. Ten cel jest jasno sformułowany w 43,10:

Wy jesteście moimi świadkami - wyrocznia Jahwe i moimi sługami, których wybrałem, abyście mogli poznać $\left(t \bar{e} d^{\top} \hat{u}\right)$ i uwierzyć Mi (woța ămînû $1 \hat{r})$,

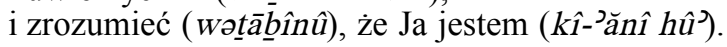

Każdy z trzech czasowników określających cel świadectwa zakłada wejście w żywą, dynamicznie rozwijającą się relację z Jahwe, która jest osobistym doświadczeniem Jahwe jako jedynego, prawdziwego, zbawiającego Boga ${ }^{13}$. Izrael musi najpierw sam dojść do wiary w Jahwe, by stać się wobec narodów żywym świadectwem jedynego, zbawiającego Boga. Już sam akt włączenia się w proces jako świadek będzie ze strony Izraela potwierdzeniem wydanego wcześniej werdyktu

${ }^{11}$ Por. Berges, Jesaja 40-48, 279.

12 Podobną rolę mają odegrać świadkowie, których mają powołać bóstwa obcych narodów (por. '`ẹdêhem w Iz 43,9). Inne przykłady tego rodzaju konstrukcji wskazujące na świadka obrony w Hi 10,17; 16,19; Iz 44,9 (por. Bovati, Ristabilire la giustizia, 243).

${ }^{13}$ Por. Melugin, The Formation of Isaiah 40-55, 110; Oswalt, The Book of Isaiah. Chapters 40-66, 146. 


\section{Przedmiot świadectwa}

Komentując tekst Iz 43,10-13, C. Westermann stwierdza, że ,przed Deutero-Izajaszaem nikt nie wypowiedział bardziej jednoznacznego i radykalnego zdania o Bogu Izraela jako Bogu jedynym" ${ }^{14}$. Zaproponowana poniżej struktura retoryczna tej wyroczni wymaga w kilku miejscach komentarza filologicznego, co zostanie dokonane $\mathrm{w}$ trakcie prezentowania zawartych w nim argumentów na rzecz jedyności Jahwe jako Boga. Elementy znaczące retorycznie zostały wyeksponowane graficznie.

${ }^{10}$ Wy jesteście moimi świadkami - wyrocznia Jahwe i moimi sługami, których wybrałem, abyście mogli poznać i uwierzyć Mi, i zrozumieć, że JA JESTEM,

przede Mną nie był uformowany żaden bóg, ani po Mnie nie będzie.

${ }^{11} \mathrm{Ja}$, Ja jestem Jahwe, i nie ma poza Mną wybawcy.

${ }^{12} \mathrm{Ja}$ oznajmiłem i wybawilem, i ogłosiłem, i nie byłem pośród was obcy.

Wy jesteście moimi świadkami - wyrocznia Jahwe i Ja jestem Bóg.

${ }^{13}$ Owszem, od początku J J JESTEM.

I nikt z mojej rekki nie wyrwie.

Uczyniłem i kto może to odwrócić?

Analizowany tekst wyroczni składa się z czterech urywków, które tworzą strukturę chiastyczną A (w. 10) B (w. 11) B' (w.12) A' (w. 13). O paralelizmie między urywkami A i A' stanowi powtórzenie formuły autoprezentacji ’ănî hû̉, przetłumaczonej jako „Ja jestem”. Ta relacja jest wzmocniona przez występujące tylko w tych urywkach okoliczniki czasu: miyyôm z w. 13a, przethumaczony jako „od początku” (dosłownie „od dnia”, przy prawdopodobnej elizji „pierwszego”) koresponduje z wyrażeniami „przede

${ }^{14}$ Westermann, Isaiah 40-66, 123. 
Mną” i ,po Mnie” (w. 10ef), które wskazują na istnienie Jahwe jako rodzaj cezury czasowej. Urywki A i A’ łączy również obecność czasowników opisujących działanie: w w. 10e pojawia się czasownik yāṣar (,kształtować, formować”), zaś w w. 13c - czasownik pācal („,czynić, robić"). W związku z czasownikiem yāṣar pozostaje też rzeczownik ,ręka”, która stanowi niezbędny narząd przy wykonywaniu czynności formowania (lepienia).

W przypadku urywków B i B' zauważa się paralelizm między formułami autoprezentacji „Ja, Ja jestem Jahwe” ( 'ānōk̂î 'ānōkî yhwh w w. 11a) i „Ja jestem Bogiem” ( 'ănî-’̄ēl w w. 12d), przez co zostaje podkreślone, iż Jahwe jest Bogiem. Urywki łączy również czasownik yāša ${ }^{c}$ w Hi: w w. $11 \mathrm{~b}$ w formie participium môšî ${ }^{a c}$ (,,zbawca, wybawca"), zaś w w. 12a w formie perfectum hôša ${ }^{c} \hat{\imath}$ (,wybawiłem, zbawiłem”).

O dynamice analizowanej jednostki stanowi również powtórzenie formuły wezwania na świadka: „Wy jesteście moimi świadkami - wyrocznia Jahwe" (ww. 10a.12c). Biorąc pod uwagę bezpośredni kontekst urywków A i B', w których one występują, służą one podkreśleniu, iż Izrael pozostaje w relacji tylko z Jahwe, a nie z jakimiś nieistniejącymi bogami (w. 10ef). Co więcej, Jahwe ,nie jest obcy pośrodku" swego ludu (w. 12b) ${ }^{15}$.

${ }^{15}$ Występująca w w. 12b syntagma ’ên bāknem zār została przetłumaczona jako ,nie byłem pośród was obcy”. Trudność stwarza przekład przymiotnika zār (por. zestawienie różnych możliwości przekładu analizowanej syntagmy w: Stachowiak, Księga Izajasza 40-66, 120. Zwykle w komentarzach proponuje się lekturę: ,a nie jakiś cudzy bóg pośród was”, co zdaje się odwoływać do Pwt 32,12 (,Jahwe sam go prowadził, a nie było z nim żadnego boga obcego [ 'ềl nēkāar]'). Taka interpretacja nie jest właściwa w kontekście analizowanej wyroczni, w której brak jest nawiązania do exodusu i wędrówki przez pustynię (por. Koole, Isaiah III. Chapters 40-48, 313). Tymczasem powiązanie syntaktyczne między członami w. 12 pozwala na interpretację w. $12 \mathrm{~b}$ jako apozycji do zaimka ’ānōk̂î, który może być odczytane jako podmiot wyrażenia ’ên bākem zār, odnosząc tym samym to wyznanie do Jahwe. Taki przekład m.in. w: Westermann, Isaiah 40-66, 124; Koole, Isaiah III. Chapters 40-48, 313. 
Strukturę chiastyczną ww. 10-13 można oddać schematycznie w następujący sposób:
A (w. 10)
jedyność bycia Jahwe
$\mathrm{B}($ w. 11)
B' (w. 12)
$\mathrm{A}^{\prime}$ (w. 13) jedyność Jahwe jako Wybawcy
jedyność Jahwe jako przepowiadającego
i realizującego wybawienie
jedyność działania Jahwe.

Jedyność Jahwe w A i A' zostaje podkreślona w wymiarze czasowym: żaden bóg nie został utworzony ani przed, ani po Jahwe (A). Jedynym istniejącym Bogiem od samego początku jest Jahwe (A'). Jeśli nieistniejący bogowie do swego zaistnienia potrzebowaliby działania kogoś drugiego, który by ich uformował (A'), to Jahwe jest od początku jedynym działającym Bogiem w świecie, którego czynów nikt nie jest w stanie odwrócić. Nie Jahwe jest kształtowany przez innych, ale to Jego ręka działa w historii. Jedyność Jahwe, prezentowana w skrajnych urywkach w wymiarze czasowym, zostaje odczytana w urywkach centralnych B i B' na płaszczyźnie historiozbawczej. Skoro Jahwe jest jedynym Bogiem, to pozostaje on również jedynym Zbawcą swego ludu (B). Wydarzenia zbawcze, które są udziałem Izraela, zostały zapowiedziane i zrealizowane przez Jahwe (B').

Nie ma wątpliwości, że Deutero-Izajasz jest „świadkiem koronnym starotestamentalnego monoteizmu"16. Anonimowy prorok wygnania czyni decydujący krok w przejściu od ,idei nieporównywalności Boga w kierunku Jego absolutnej jedyności. [...] Wyraża się wraz z nim [prorokiem] jasno monoteizm teoretyczny" 17 . Bazując na przeprowadzonej analizie retorycznej Iz 43,10-13, wskaże się główne argumenty za jedynością Jahwe. One to stanowią przedmiot doświadczenia Izraela, który ma być ich świadkiem.

Z punktu widzenia retorycznego kluczową rolę odgrywa formuła autoprezentacji ’ănî hî̀', która obramowuje

${ }^{16}$ Małecki, Monoteizm w Księdze Deuteroizajasza, 207.

17 Bonora, Isaia 40-66, 72. 
mowę objawieniową Boga, będąc pierwszym (w. 10a) i ostatnim słowem Jahwe (w. 13a). Ta formuła autoprezentacji pojawia się u Deutero-Izajasza w formie ănî h $\hat{u}^{\supset}$ jeszcze pięciokrotnie $(41,4 ; 42,8 ; 46,4 ; 48,12 ; 52,6)$, zaś w formie 'ānōkî hû ${ }^{J}-$ dwukrotnie $(43,25 ; 51,12)$, w pełni zasługując na miano formuły monoteistycznej ${ }^{18}$. Formuła wykorzystująca zaimek 'ānōk̂î pojawia się w zdaniach, w których pełni on funkcję podmiotu dla czynności opisywanych dalej w orzeczniku - w 43,25: Jahwe ,pprzebacza"; w 51,12: Jahwe ,pociesza". W tych zdaniach zaimek $h \hat{u}^{\supset}$ służy intensyfikacji podmiotu: „Ja właśnie”/,Ja tylko” przebaczam, pocieszam. Jedyne wystąpienie tej formuły poza Księgą Izajasza - w Pwt 32,2919 - pozwala wnioskować, iż służy ona podkreśleniu jedyności czy ekskluzywności Jahwe jako Boga. W Iz 41,4 i 48,12 ta jedyność Jahwe ujawnia się w wymiarze czasowym, gdyż Jahwe jest Tym, który jest „,pierwszy” i „ostatni”. Ten dwumian w 41,4 pojawia się w formie nieco zmodyfikowanej, gdyż Jahwe jest ,pierwszy” i pozostaje ,z ostatnim”. Zatem Jahwe jest obecny od początku do końca w historii, w całym jej przebiegu. Podobny aspekt czasowy ekskluzywności Jahwe niesie ze sobą ta formuła w 43,10.12, przy czym nie chodzi tylko o ,bycie”, ale również o ,działanie” Jahwe (szczególnie w w. 12). Sensu zaimka $h \hat{u}^{\supset}$ stosowanego w tej formule należy szukać w 41,4; 42,8 i 52,6. Pierwszy z tych trzech tekstów zawiera zestawione ze sobą paralelnie dwie formuły: 'ănî yhwh oraz 'ănî hî̀, z czego wynika, że $h \hat{u}^{\supset}$ funkcjonuje jako ekwiwalent imienia Bożego. Potwierdza to wypowiedź Jahwe w 42,8 i 52,6, gdzie zwrot ’ănî $h \hat{u}^{\supset}$ identyfikuje ze ,swoim imieniem”. Analizowana formuła podkreśla przede wszystkim osobową obecność Boga ze swoim ludem, jak można wnioskować z jej wystąpienia w 46,4 i 52,6: w pierwszym tekście tak przedstawia się Jahwe, który mówi o swoim stałym i kon-

${ }^{18}$ Gołębiewski, Hymny samopochwalne Jahwe, 192.

${ }^{19}$ W Ps 102,28 pojawia się ona na ustach oranta, który zwraca się jej słowami do Boga: wəวattāh-hû̉. 
sekwentnym „noszeniu” Izraela, w drugim zaś o swojej relacji do „swojego ludu”.

Ten związek Izraela $\mathrm{z}$ Jahwe zawiera się $\mathrm{w}$ formule autoprezentacji 'ānōknî 'ānōk̂î yhwh w 43,11, paralelnej do wyrażenia 'ănî- $\bar{e} l \mathrm{l}$ 43,12d. Formuła samookreślenia „Ja jestem Jahwe" pozostaje w ścisłym związku z wyjściem Izraelitów z niewoli egipskiej ${ }^{20}$. Analiza wystąpień tego zwrotu w tekstach Pięcioksięgu pozwala sądzić, iż niezależnie od tradycji, w której się pojawia, zwraca uwagę „na pierwotny związek samookreślenia Boga $\mathrm{z}$ uwolnieniem narodu z niewoli egipskiej i z obowiązkiem przymierza"21. Przekazanie tej formuły łączy się z osobą Mojżesza i objawieniem, które otrzymał on od Boga, co znajduje najpełniejszy wyraz w Wj 6,2-8. Powtórzona tam trzykrotnie fraza „Ja jestem Jahwe” określa najpierw treść objawienia przekazanego Mojżeszowi (ww. 2.6), wyznacza związek między Jahwe i uwolnieniem z Egiptu (w. 6) oraz zamyka formułę przymierza (formułę wzajemnej przynależności), w której Jahwe określa się wobec Izraelitów jako ,ich Bóg" (w. 7). Ta formuła autoprezentacji w wypowiedziach Jahwe w tekstach Deutero-Izajasza dowodzi, iż Jahwe wciąż działa w historii swego ludu. Dla Izraelitów przebywających na wygnaniu w Babilonii analogia z niewolą egipską jest samo narzucająca się: Jahwe zapowiada im, że raz jeszcze doświadczą Jego zbawczej obecności w swojej historii ${ }^{22}$. Paralelne zestawienie formuły „Ja jestem Jahwe” z wyrażeniem „Ja jestem Bogiem” w Iz 43,11a.12d służy podkreśleniu jedyności Jahwe jako Boga. Rzeczownik 'ē 1 bez przydawki wskazuje w tekstach Deutero-Izajasza na Kogoś, kto rzeczywiście jest Bogiem. Taki sens tej formuły w 43,12 znajduje potwierdzenie w dwóch pozostałych

${ }^{20}$ Szczegółową analizę tej formuły pod kątem historii formy i tradycji przeprowadził: Zimmerli, „Io sono Jahvé”, 18-44. Na gruncie polskim analogiczne opracowanie znajduje się w: Gołębiewski, Hymny samopochwalne Jahwe, 44-56 (autor omawia formuły autoprezentacji w różnych tradycjach Starego Testamentu), 185-146 (autor analizuje występowanie tych formuł w tekstach Deutero-Izajasza).

${ }^{21}$ Gołębiewski, Hymny samopochwalne Jahwe, 47.

${ }^{22}$ Por. Gołębiewski, Hymny samopochwalne Jahwe, 193. 
wystąpieniach tego wyrażenia w tekstach Deutero-Iza-

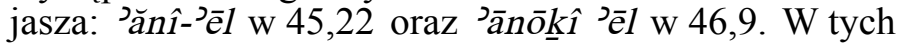
miejscach, zaraz po tej formule, pojawi się stwierdzenie ekskluzywności wə’ên 'ôd (,,i nikt inny”), które podkreśla jedyność Jahwe jako Boga.

To doświadczenie jedyności Jahwe jest dostępne i weryfikowalne w historii, która jest udziałem Izraela. To ona jest prowadzona słowem Jahwe, który nie tylko przepowiada wydarzenia, ale i je urzeczywistnia: ' $\bar{a} n \bar{o} \underline{k} \hat{i}$ higgad tî̀ wohôša ${ }^{c} t \hat{i}$ wohišma ${ }^{\complement} t \hat{\imath}$ (,Ja oznajmiłem i wybawiłem, i ogłosiłem”, 43,12). To wyznanie kontrastuje z wyzwaniem, jakie Jahwe rzuca bożkom obcych naro-

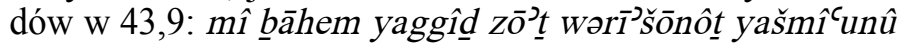
(,Kto z was może oznajmić to i ogłosić dawne wydarzenia"), które wobec braku odpowiedzi demaskuje ich nieistnienie. Tylko Jahwe jest zdolny zapowiedzieć przyszłe wydarzenie. Ta prawda jest podnoszona przez Jahwe nie tylko w polemice z bożkami pogańskimi (por. 41,22; 42,9; $45,21 ; 48,3.5)$. Stanowi ona jeden z elementów, który służy dodaniu Izraelitom odwagi, zapewniając ich o zbawczej obecności Boga w ich przeszłej, teraźniejszej i przyszłej historii (por. 40,21; 44,8; 45,19; 46,10). Panowanie Jahwe nad przeszłością i teraźniejszością znajduje potwierdzenie w Jego zdolności nie tylko przewidzenia tego, co nastąpi, ale przede wszystkim w urzeczywistnieniu i doprowadzeniu do realizacji swego słowa. Stąd też o sobie mówi w 43,12, że nie tylko „oznajmił i obwieścił”, lecz również „wybawił". W kontekście analizowanej wyroczni termin

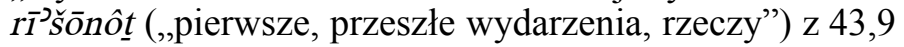
winien być interpretowany w świetle polecenia ,niewspominania przeszłych wydarzeń" w 43,18, które tożsame są z pierwszym exodusem. Inne wystąpienia terminu $r \bar{\imath} \breve{s} \bar{o} n o ̂ t$ w Księdze Pocieszenia pozwalają sądzić, że prorok posługuje się nim dla wskazania także innych wydarzeń zbawczych z historii, które zapowiedział i zrealizował Jahwe (por. 41,$22 ; 46,9 ; 48,3)^{23}$. W tym kontekście zaimek $z \bar{o}^{\top} \underline{t}$ w 43,9 skraca perspektywę przeszłości i zadaje się odnosić

${ }^{23}$ Por. North, ,The «Former Things»”, 123-124. 
już do wydarzeń rozgrywających się na oczach Izraelitów przebywających na wygnaniu, a więc do postępującego triumfu Cyrusa, który doprowadzi ostatecznie do upadku Babilonii ${ }^{24}$. Równocześnie Jahwe panuje nad przyszłością, gdyż tylko On jest w stanie zapowiedzieć ,,rzeczy przyszle” $(41,22)$ i ,nowe” $(42,9)$, jak również te „,nowe rzeczy uczynić" $(43,19)$.

W ten sposób Jahwe daje się poznać nie tylko jako „Stworzyciel” (bôrē"h) i „Twórca” (yôsēer) Izraela $(43,1)^{25}$, ale również jako jedyny Twórca dziejów całego świata, co zostaje wyeksponowane w paralelnych wersetach $43,10.13$. Wiersz 10 . ma wyraźny ton polemiczny ze starożytnymi teogoniami, w których bóstwa są ,kształtowane" z wcześniej istniejącej materii. Sięgnięcie w tym kontekście po czasownik yāṣar uderza w praktykę ,produkowania" materialnych wyobrażeń bożków, ironicznie przedstawioną w 44,9-20, która rozpoczyna się od przywołania yōṣrê-p̄esel („twórców bożków”; czasownik yāṣar jeszcze w ww. 10.12). Jahwe istnieje „od początku”, w sposób absolutny panuje w świecie, co jest oddane metaforą „Jego ręki”26 (43,13a). Ta myśl znajduje potwierdzenie w w. 13b, w którym Jahwe stwierdza, iż nikt nie jest w stanie zmienić ( $\breve{s} u \underline{b}$ w $H i)$ tego, co On uczynił ( $\left.p \bar{a}^{c} a l\right)$. Wprawdzie komentatorzy nie przypisują czasownika $p \bar{a} \bar{c}^{c} \mathrm{l}$ do pola semantycznego stwarzania (w sensie creatio pri$m a)^{27}$, to jednak wyrażenie $p \bar{o}^{\complement}$ al yāday (,dzieło moich rąk") w 45,11 wyraźnie odnosi się do stworzenia świata

${ }^{24}$ Por. Koole, Isaiah III. Chapters 40-48, 305; Goldingay - Payne, A Critical and Exegetical, 284.

${ }^{25}$ Ta sama myśl, oddana za pomocą czasowników bārāa ${ }^{h}$ i yāṣar, występuje w Iz 43,7.15.21; 44,2.21.24; 45,11.

${ }^{26} \mathrm{~W}$ połączeniu z czasownikiem nāṣal w Hi może chodzić o metaforę karzącej interwencji Jahwe (por. Hi 10,7; Oz 2,12). Jednakże w Iz 43,13 nie ma żadnego odniesienia do nieprzyjaciół Boga, przez co sens tego wyrażenia jest bliższy Pwt 32,39, gdzie ta sama kombinacja (yād + nāṣal w Hi) pojawia się w kontekście stwierdzenia jedyności Jahwe jako Boga, który ma absolutną władzę nad życiem i śmiercią (por. Koole, Isaiah III. Chapters 40-48, 315).

${ }^{27}$ Tak np. Koole, Isaiah III. Chapters 40-48, 141. 
$(45,12)$, a następnie do historii współczesnej słuchaczom proroka - powołania przez Jahwe Cyrusa $(45,13)$. Wybór zatem czasownika $p \bar{a}^{-}$al służy podkreśleniu przez Jahwe, iż On jest twórcą całych dziejów świata - zarówno tych związanych z creatio prima, jak i tych idących przez wieki aż do chwili obecnej (creatio continua). Równocześnie czasownik ten zaznacza uniwersalny wymiar panowania Jahwe w świecie, co znajduje potwierdzenie w 41,4: Jahwe

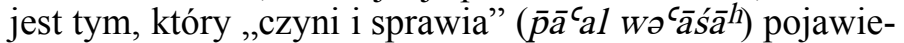
nie się na scenie międzynarodowej Cyrusa (por. 41,2-3), ale też stoi za powołaniem do istnienia pokolenia ludzi

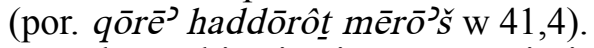

Jahwe objawia się ostatecznie jako jedyny Zbawca Izraela $(43,11 \mathrm{~b})$. On jako jedyny przepowiadał przeszłe wydarzenia ich historii, których urzeczywistnienie było dziełem Jego rąk. Dlatego w żaden sposób nie był „pośród nich obcy" (w. 12b). To stwierdzenie, które może wydawać się formalne i pozbawione uczucia, nabiera głębszego znaczenia w kontekście formuł autoprezentacji. Nie chodzi tylko o to, że Jahwe poprzez swoje działanie dawał się poznać Izraelowi. Formuły samoobjawieniowe ujawniają, że Jahwe związał się z Izraelem jako ,ich Bóg”. Ta osobowa relacja oparta jest na miłości Boga do swego ludu, co zostaje wyakcentowane w wyroczni $43,1-7$, poprzedzającej bezpośrednio analizowaną mowę z 43,8-13. Po raz pierwszy w Księdze Pocieszenia Pan Bóg mówi wprost Izraelowi, że go „stworzył” i ,ukształtował” $(43,1)$. Relacja Stwórca-stworzenie zostaje przeniesiona na poziom relacji osobowej Ojciec-dziecko. Zawiązały się niemal więzy krwi, skoro Jahwe podejmuje działania właściwe osobie $g \bar{o}$ 'èla, zobowiązanego przez więzy krwi do wykupienia swego krewnego (w. 1). W istocie „nazwanie po imieniu” Izraela przez Jahwe dokonuje się przez formułę adopcyjną: „Tyś mój” (w. 1), znaną z Rdz 48,5. Izrael rzeczywiście zostaje nazwany imieniem Jahwe, stając się Jego własnością (por. 44,5). Nie jest to tylko akt prawny, ani tym bardziej próba zniewolenia Izraela, gdyż stanowi wyraz miłości Jahwe do utworzonego sobie ludu. Przewyższa on swoją wartością Egipt, Kusz i Sabę (por. 43,3), gdyż 
Izraelici są drogocenni w oczach Jahwe (por. czasowniki yāqar i kāb $\underline{a} a \underline{d}$ w 43,4), są Jego córkami i synami $(43,6)$, z którymi związany jest miłością. Jej wyznanie w 43,4: Jănî Jăhab tîk $\bar{a}$, przez emfatyczny zaimek osobowy podkreśla intymność $i$ intensywność tej relacji ze strony Jahwe.

\section{Przeszkody na drodze świadectwa}

Przedmiotem sporu Jahwe z obcymi narodami i czczonymi przez nie bożkami (por. Iz 41,1.21-23) jest kwestia Jego jedyności jako Boga. Argumentacja użyta przez Jahwe odwołuje się do historycznego doświadczenia przez Izrael zbawczego działania Jahwe. $\mathrm{Z}$ tego powodu Izrael ma wszelkie dane ku temu, by być wiarygodnym świadkiem. Sytuacja nie jest jednak tak oczywista, ponieważ to świadek musi jako pierwszy dojść do poznania i uwierzenia, że Jahwe jest jedynym Bogiem (por. 43,10). Dlaczego świadek musi najpierw otworzyć się na świadectwo, którym ma podzielić się ze światem?

Zaskakuje określenie Izraela jako świadka w 43,8: ‘am-`iwwēr wo ‘̂̀nayim yēš woḥēršîm wo’oznayim lāmô. Waw koordynujące w tym zdaniu pozwala na interpretowanie sytuacji ludu w dwojaki sposób ${ }^{28}$, co oddają poniższe tłumaczenia:

a) negatywny: „lud ślepy, choć mający oczy, i głuchy, choć mający uszy";

b) pozytywny: „lud ślepy, mający jednak oczy, i głuchy, mający jednak uszy".

Przy pierwszym przekładzie chodziłoby o rodzaj oskarżenia kierowanego do Izraela, przy drugim - pozostaje wciąż możliwa perspektywa dania świadectwa, które odwoływałoby się do osobistego doświadczenia i asystowania zdarzeniom mającym być przedmiotem świadectwa. Niezależnie jednak od przyjętej formy przekładu trudności na drodze świadectwa są przedstawione w analizowanym wersecie jako problem percepcji związany z dwoma

${ }^{28}$ Por. Baltzer, Deutero-Jesaja, 218. 
zmysłami: słuchu i widzenia. Nie chodzi w tym wypadku o upośledzenie fizyczne tych narządów, na co wskazuje powracająca kilka razy u Deutero-Izajasza charakterystyka Izraela jako ludu ślepego i głuchego. W kontekście poprzedzającym Iz 43,8 należy zwrócić uwagę przede wszystkim na wyrocznię w 42,18-25, szczególnie w. 18-20.23.

Człowiek potrzebuje uszu i oczu, by słyszeć i widzieć. W 42,18 pojawia się wezwanie do słuchania i widzenia skierowane do ludzi ,głuchych" i ,ślepych”, co zakłada, że adresaci tego apelu są w stanie i słyszeć, i widzieć. Ponieważ jako pierwsza czynność zostaje wymienione słuchanie, dalsza analiza skupi się na czasownikach opisujących ten właśnie akt percepcji w Księdze Izajasza, by zdiagnozować przyczyny niesłuchania, a w konsekwencji również niewidzenia.

W Iz 42,18 czynność słuchania oddana jest czasownikiem šăma $`$. W 42,23 obok tego czasownika pojawia się गāzan w Hi i qāšab w Hi. Struktura tego wersetu jest paralelna, jakkolwiek z drugiego stychu wynika, że czynność oddana czasownikiem $q \bar{a} \bar{s} a \underline{b}$ stanowi uprzedni warunek dla aktu słuchania. Podobny wniosek można wysnuć dla czasownika 'āzan, gdyż w 28,23 oba te czasowniki, występując w paralelnych stychach, są wskazane jako element warunkujący słuchanie. W takim też znaczeniu te dwa czasowniki pojawiają się w 51,4, co pozwala na uznanie ich za synonimiczne. Zatem w przypadku czasowników गāzan i qāšab chodzi o moment poprzedzający i warunkujący czynność słuchania - o skupienie i uwagę konieczne do słuchania, o wewnętrzny stan ducha, który pozwala na usłyszenie słów wypowiadanych przez kogoś. Do tego potrzebna jest również decyzja, by słuchać kogoś drugiego.

W tym kontekście należy odczytywać zachętę do otwarcia uszu (czasownik pātaḥ w 35,5; 48,8; 50,5), która występuje paralelnie $\mathrm{z}$ wezwaniem do otwarcia oczu (czasownik pāqaḥ w 35,5; por. 37,17 [w paraleli z wyrażeniem nātăh w Hi + 'ōzen - „nakłonić ucho”]; 42,7). To zamknięcie nie jest spowodowane jakąś chorobą uszu, lecz jest konsekwencją decyzji człowieka, który nie chce słuchać. Taką decyzję podejmuje na przykład człowiek 
sprawiedliwy, który ,zamyka uszy” ( 'ạtam + 'ōzen), by nie słuchać o złu $(33,15$; por. 32,2). Jednakże same otwarte uszy nie wystarczają, by usłyszane słowo zostało przyjęte (por. 42,20b).

Za decyzją słuchania musi pójść gotowość przyjęcia usłyszanego słowa, wprowadzenia go w serce - w centrum rozumowe, wolitywne i emocjonalne człowieka. To przejście czy bardziej jeszcze finalizacja aktu słuchania, wyrażona jest w 42,25 zwrotem „wziąc do serca” (śîm cal-lēb). Nie chodzi w tym wypadku tylko o poważne potraktowanie tego, co się słyszy, lecz o czynność wniknięcia w głębię słyszanego słowa, by odkryć jego znaczenie (por. bîn w Hi jako synonim sî̀m cal-lē $\underline{b}$ w 57,1). To wymaga pamięci o usłyszanym słowie (por. zāk kar ako synonim śîm cal-lēb w 57,11). Można zatem mówić o akcie interioryzacji słowa, powracania wciąż do niego, poszukiwania wciąż na nowo jego znaczenia, by to słowo mogło niejako od wewnątrz kształtować człowieka, stając się częścią jego życia (ciała). Taką dynamikę komunikacji zauważa się w Ez 40,4. We fragmencie tym wyrażenie sîm lē $\underline{b}$ stanowi czynność będącą konsekwencją wcześniejszego widzenia oczami i słuchania uszami.

W analogiczny sposób można diagnozować akt niewidzenia. Samo posiadanie oczu nie przekłada się koniecznie na widzenie (Iz 42,18b; 43,8a). Człowiek może je świadomie zamknąć (por. 'āṣam w 33,15), „zapieczętować” ( $\breve{s} \bar{a}^{c} a^{c}$ w 32,3). Samo otwarcie oczu też nie wystarczy, gdyż potrzeba „strzec” tego, co się ujrzało ( šāmar w 42,20). Chodziłoby w tym wypadku o czynność pamiętania, zachowywania w sercu, by powracać do szukania znaczenia ujrzanej rzeczy (por. Rdz 37,11; Prz 4,21) ${ }^{29}$.

Gdzie leży przyczyna głuchoty i ślepoty Izraela? W Iz 48,8 niesłuchanie ze strony swego ludu Pan Bóg denuncjuje słowami: „Nie słyszałeś, nie poznałeś, twoje uszy nie były otwarte, ponieważ byłeś wiarołomny ( $b \bar{a} \bar{g} a \underline{d}$ ) i zbuntowany ( $\left.p \bar{a} \overline{s ̆ a}^{c}\right)^{\prime}$. Sam Izrael uznaje tę prawdę o sobie w 42,24, kiedy przyznaje: „Czy nie przeciw Jah-

${ }^{29}$ Por. Koole, Isaiah III. Chapters 40-48, 270. 
we zgrzeszyliśmy i nie chcieliśmy chodzić jego drogami ani słuchać Jego Prawa?” Nieposłuszeństwo przymierzu z Jahwe prowadzi Izrael do grzechu. Jednakże sami Izraelici ograniczali kwestię posłuszeństwa tylko do sfery kultu (por. 43,23-24). Ale nawet i w obszarze kultu ofiarniczego Pan Bóg ujawnia wykroczenia Izraelitów, by za chwilę zwrócić uwagę na bliżej niesprecyzowany grzech ,ich pierwszego ojca" oraz ,występki ich pośredników” $(43,27)^{30}$. Gdy uwzględnić postać Sługi Jahwe, której wystąpienia w wyroczniach Deutero-Izajasza wpisują się w fabułę sporu sądowego zainicjowanego w rozdz. 41, wówczas znajduje potwierdzenie teza, iż niesłuchanie (głuchota) i niewidzenie (ślepota) Izraelitów jest konsekwencją ich nieposłuszeństwa wobec Jahwe. Przeciwieństwem ich postawy jest Sługa, który w tzw. trzeciej pieśni $(50,4-9)$ dzieli się swoim doświadczeniem słuchania Boga. Wobec słowa Boga Sługa przyjmuje postawę ucznia, który od rana poszukuje słów swego nauczyciela (w. 4), jest otwarty i czujny na każde wypowiedziane przez niego słowo. Ta relacja typowo ,szkolna” wskazuje na słuchanie jako pewien proces rozciągnięty w czasie, rodzaj formacji nie tylko intelektualnej, uczenie się na bazie wcześniej otrzymanej lekcji. Taki też jest sens wyrażenia „otworzyć ucho" (w. 5), odnoszącego się do objawienia, które Sługa otrzymuje i przyjmuje od Boga.

Kontrast między Sługą Jahwe a Izraelem dotyczy zatem nie tylko kwestii posłuszeństwa, ale również objawia

${ }^{30}$ Oba te zwroty stwarzają problem w ustaleniu tożsamości inkryminowanych podmiotów. W przypadku ’āblîk $\underline{a}$ hāri’̌̌son komentatorzy zakładają, że chodzi o Abrahama lub Jakuba, jakkolwiek sam tekst i kontekst nie pozwala na jednoznaczną identyfikację tej postaci i określenie charakteru jej występku. Wydaje się, że należy raczej wykluczyć osobę Abrahama, gdyż ten patriarcha jest postrzegany pozytywnie w Iz 41,8. Trudno też ustalić znaczenie terminu molîșey $\underline{k} \bar{a}$ i w konsekwencji osób, do których on się odnosi. Mając na uwadze wystąpienia tego rzeczownika w Rdz 42,43 („tłumacz”), Hi 33,23 (,pośrednik”) i 2 Krn 32,31 (,wysłannik”), przyjmuje się sens ,liderzy, pośrednicy, rzecznicy", łącząc go w Iz 43,27 z kapłanami i prorokami. Por. dyskusję nad znaczeniem tych terminów w: Berges, Jesaja 40-48, 313-315. 
się na płaszczyźnie otwartości na nowość, jaką niesie ze sobą słowo (objawienie) Jahwe. $Z$ tego powodu Pan Bóg apeluje do ludu, by „nie wspominał wydarzeń minionych, nie rozważał rzeczy dawnych” $(43,18)$, gdyż „oto [Bóg] czyni rzecz nową, teraz pojawia się" $(43,19 a)$. Świadek ma pamiętać o przeszłych zdarzeniach, gdyż one są podstawą jego świadectwa. Percepcja przeszłych wydarzeń nie ma ograniczyć się tylko do ich ,zobaczenia” i ,usłyszenia”, lecz ma prowadzić do odkrycia ich znaczenia, by móc o nich mówić wobec innych, jak również w ich świetle rozpoznawać działanie Boga w teraźniejszości i przyszłości. Przeszłe wydarzenie to wyjście z Egiptu (por. 43,16-17), które urasta do rangi paradygmatu zbawczego działania Jahwe w historii Izraela. To w tych wydarzeniach Izraelici mają rozpoznać jedyność Jahwe jako Boga. Równocześnie mają odkryć Jego zbawczą obecność we współczesnej swojej historii, która w ich przekonaniu jest porzucona i zapomniana przez Jahwe (por. 40,27; 49,14). Tego rodzaju myślenie wydaje się konsekwencją pewnej schematyczności w patrzeniu na Boga, wobec którego oczekuje się wciąż tego samego sposobu działania. Tymczasem Jahwe jest Stwórcą, a nie jakimś bożkiem, który byłby zmuszony do powtarzania wciąż tej samej czynności. Wobec przeszłej historii Izraelici nie potrafią odczytać znaczenia obecnego doświadczenia wygnania, nie dostrzegają w nim Bożej pedagogii i kary (por. 42,25), są przekonani, że obecny czas stoi w sprzeczności z przeszłym działaniem i objawieniem się Jahwe w ich dziejach. W pewnym sensie można powiedzieć, że nierozpoznanie Boga pozostaje w związku z nierozpoznaniem obecnej prawdy o sobie, o swoim grzechu i występku wobec Jahwe, któremu imputuje się własną niewierność. Bez uznania prawdy o sobie (por. 43,26) lud nie będzie potrafił otworzyć się na nowy exodus, który właśnie teraz dokonuje się za sprawą Pana Boga (por. 43,19-20). W rezultacie nie podejmie swojej roli świadka, który ma „opowiadać Jego chwałę" $(43,21)$. 


\section{Brakujące Świadectwo Izraela a Świadectwo SŁugi Jahwe}

Rozdz. 43 w strukturze Deutero-Izajasza wskazuje na punkt zwrotny w sporze, który Jahwe wiedzie z obcymi narodami i ich bożkami. Spór zawiązany w rozdz. 41 prowadzi do wezwania przez strony swoich świadków. W kontekście samego zawiązania sporu nie jest to konieczne, bo Jahwe już wcześniej dowiódł swojej jedyności, rzucając prowokacyjnie wyzwanie pogańskim bożkom, by „objawiły to, co ma nadejść w przyszłości, [...] by zrobiły coś dobrego czy coś złego" $(41,23)$. Po drugiej stronie nie ma żadnej reakcji. W rezultacie pretendenci obcych narodów do miana bogów nie są w stanie wystawić świadków, którzy mogliby powiedzieć o ich działaniu w świecie $(43,9)$.

Sytuacja procesowa Jahwe jest diametralnie różna. O działaniu Jahwe w świecie mogą zaświadczyć stworzone przez Niego elementy wszechświata - góry, pagórki, wyspy (por. 41,1) - towarzyszące od początku temu wszystkiemu, co czyni On dla swojego ludu. Wobec świata nie wystarczy jednak ich nieme świadectwo. Procedura sądowa wymaga świadka, który nie tylko będzie posiadał wiedzę na temat określonych faktów, ale również będzie w stanie wypowiedzieć słowo objawiające te fakty. Kimś takim jest Izrael - lud, z którym Jahwe związał się przymierzem i który jest pierwszorzędnym adresatem i beneficjentem zaangażowania się Jahwe w świecie $(43,10.12)$. Okazuje się jednak, że Izrael nie jest zdolny do złożenia takiego świadectwa. Analiza przeszkód stojących na drodze takiego świadectwa pokazała, że trudność nie leży w sferze zewnętrznej, lecz pozostaje związana z jakością samego świadka. Lud Jahwe jakby strukturalnie nie jest zdolny do złożenia świadectwa, mimo że „to wszystko widział i słyszał" $(48,6)$. Do świadectwa nie dojdzie z powodu braku ,poznania” znaczenia tych zdarzeń $(48,6)$. Nie jest to kwestia jakiegoś defektu fizycznego czy intelektualnego. Określeniu Izraelitów jako ,ludu ślepego i głuchego" towarzyszy zaskakujące dopowiedzenie, iż dzieje 
się tak, mimo że mają oni oczy i uszy. Izraelowi brakuje woli dania świadectwa, co jest spowodowane ich grzechem i nieposłuszeństwem wobec Jahwe, jak zostanie to jednoznacznie sformułowane w 48,8: „Wcale nie słyszałeś, ani nie poznałeś, ani twe ucho od dawna nie było otwarte, bo wiem, że jesteś doprawdy wiarołomny i od łona [matki] jesteś nazwany buntownikiem".

Taka sytuacja prowadzi do zaskakującej zmiany w toczącym się sporze sądowym. Lud Jahwe pozostaje głuchy i ślepy na wezwanie do słuchania i widzenia (por. 42,18), odrzuca powołanie na świadka, które wymagałoby najpierw od niego samego, ,poznania, uwierzenia i zrozumienia", że Jahwe jest jedynym Bogiem i Zbawcą $(43,10)$. W rezultacie Izrael - jak wynika z 43,26 - znajduje się po stronie inkryminowanej przez Jahwe (šāpat w Ni), który domaga się od swego ludu słowa usprawiedliwienia (sāâdaq) nie tylko w sensie obrony, ale przede wszystkim w celu odbudowania zerwanej relacji przymierza.

Jahwe nie rezygnuje ze swojego świadka. Spór z obcymi narodami i bożkami został podjęty właśnie z powodu Jego ludu $(40,27)$. W punkcie krytycznym dysputy inicjatywa wciąż należy do Jahwe, który mimo zawinionego braku świadectwa ze strony Izraela potwierdza swoje zaangażowanie wobec tego ludu, raz jeszcze stwierdzając nierozerwalną więź przymierza między sobą i ludem, który sobie wybrał i utworzył (44,1-2), i który nosi Jego imię: „Do Jahwe należę” i „Dla Jahwe” $(44,5)$. Kolejny raz Jahwe upomni się u swego ludu o świadectwo $(44,8)$. Jednakże to wołanie pozostaje bez właściwej odpowiedzi, gdyż jedyne słowo, które wypowiada Izrael w kontekście procesu, pozostaje słowem skargi i pretensji do Boga, że o nich zapomniał $(49,14)$. Potrzeba zatem innego świadka, który nie tylko doprowadzi Izrael do poznania Jahwe (por. 43,10 ), ale również przywróci go - ,usprawiedliwi” (por. 43,26) - do właściwej z Nim relacji.

W perspektywie procesowej Deutero-Izajasza należy zwrócić uwagę na cykl wyroczni nazywanych ,pieśniami o Słudze Jahwe". Pierwsza z nich - w 42,1-9 - opisuje powołanie Sługi na bycie ,przymierzem ludu i światło- 
ścią narodów" $(42,6)$. W zainicjowanym sporze Jahwe ze światem pierwszoplanową rolę odegra postać tajemniczego Sługi, przez którego dokona się ostateczne objawienie prawdy o Jahwe jako jedynym Bogu, Panu historii, Stwórcy świata ${ }^{31}$. Osoba Sługi powraca w kontekście sporu sądowego - w 49,1 i 50,7-9 - po kolejnej skardze Izraela (Syjonu) o byciu zapomnianym przez Jahwe (por. 49,14) oraz postawieniu Izraelowi przez Jahwe zarzutu o złamanie przymierza (por. 50,1-3). Zostaje zatem odtworzona sytuacja wyjściowa procesu, gdzie Bóg na skargę Izraelitów odpowiedział, prezentując swojego Sługę (42,1-9). Misja Sługi Pańskiego wykracza jednak poza doraźne oczekiwania Izraela, gdyż w osobie swego Sługi Jahwe chce doprowadzić do końca swój pierwotny, wpisany w dzieło stworzenia, zamysł przymierza ze światem. Historycznie ten plan manifestował się w Jego związku z Izraelem, który jednak swoim nieposłuszeństwem uczynił siebie istotowo niezdolnym do przyjęcia daru Bożego życia, a tym samym do dania świadectwa, które przybliżyłoby inne narody do prawdy o Jahwe. Ta zbawcza inicjatywa Boga znajdzie swoje spełnienie dzięki ofierze reparacyjnej Sługi Jahwe (por. 53,10) „usprawiedliwiającego wielu” $(53,11)$. W osobie Sługi wcieli się i urzeczywistni przymierze, do którego Bóg zaprasza wszystkich ludzi.

\section{Podsumowanie}

Przeprowadzona interpretacja wyroczni Iz 43,8-13 potwierdza intuicję Paula Ricoeura o tym tekście jako zapisie pewnej „filozofii świadectwa”. Jego koncepcja świadectwa - jako wyznanie wiary i przedstawienie faktów - budowana na kanwie tego proroctwa wymaga pewnego uzupełnienia. Przede wszystkim analiza Iz 43,8-13 nie może być oparta wyłącznie na dekontekstualizacji tekstu w sensie odczytywania go w oderwaniu od jego kontekstu literackiego i historycznego. Wewnątrz Deutero-Izajasza stano-

${ }^{31}$ Por. Pikor, „Izajaszowy Sługa Jahwe”, 19-42. 
wi on jeden z kluczowych momentów sporu sądowego, który Jahwe prowadzi z obcymi narodami i czczonymi przez nich bożkami. Wezwanie świadków przez strony jawi się jako przełom w sporze $\mathrm{i}$ to w podwójnym znaczeniu: $z$ jednej strony zostaje ostatecznie potwierdzona jedyność Jahwe jako Boga - stąd słusznie można widzieć w tym tekście manifest starotestamentalnego monoteizmu, z drugiej zaś strony dochodzi do zwrotu akcji w toczącym się sporze - Izrael z pozycji świadka Jahwe staje się sam oskarżony o odrzucenie powołania na świadka. Odsłania się pewien paradoks świadectwa, do którego są wzywani Izraelici: są świadkiem ,ślepym i głuchym”, mającym wciąż jednak oczy i uszy do rozpoznania działania Jahwe w ich historii. Potrzebna jest najpierw decyzja, by usłyszeć i zobaczyć dzieła Boga pośród siebie. Konieczna jest pewna inteligencja serca, która dotrze do zrozumienia znaczenia zbawczych czynów Boga. Jest to możliwe tylko wtedy, gdy lud przymierza odrzuci swoje dotychczasowe schematyczne patrzenie na Boga, które czyni z niego bożka na podobieństwo bóstw pogańskich zawdzięczających swoje ,bytowanie” wyłącznie dziełom rąk ludzkich. Celem sporu nie jest triumf Boga, który przyniesie unicestwienie Jego adwersarzy. Pragnieniem Jahwe od samego początku istnienia świata jest przymierze, w którym każdy człowiek - nie tylko członek ludu wybranego - doświadczy Jego zbawczej miłości. W tym celu Bóg przez proroka zapowiada innego świadka - Sługę Jahwe. On to nie tylko doprowadzi świat do poznania prawdy o Jahwe, ale również usprawiedliwi Izrael i inne narody, stając się ,,przymierzem ludu" $(42,6)$.

\section{Bibliografia}

Baltzer K., Deutero-Jesaja (KAT 10/2; Gütersloh 1999).

Berges U., Jesaja 40-48 (HThKAT; Freiburg - Basel - Wien 2008).

Bonora A., Isaia 40-66. Israele: servo di Dio, popolo liberato (LoB 1/19; Brescia ${ }^{2}$ 1999). 
Bovati P., Ristabilire la giustizia. Procedure, vocabolario, orientamenti (AnBib 110; Roma ${ }^{2}$ 1997).

Goldingay J. - Payne D., A Critical and Exegetical Commentary on Isaiah 40-55. I. Commentary on Isaiah 40,1-44,23 (ICC; London - New York 2006).

Gołębiewski M., „Wizja odnowy Izraela (Księga Izajasza 40-55; 56-66)", Wielki świat starotestamentalnych proroków. II. Od końca Niewoli Babilońskiej i proroctw Deutero-Izajasza do apokaliptyki Daniela (red. J. Frankowski) (Wprowadzenie w Myśl i Wezwanie Ksiąg Biblijnych 5; Warszawa 2001) 11-31.

Gołębiewski M., Hymny samopochwalne Jahwe u Deutero-Izajasza (40-48). Studium literacko-krytyczno-teologiczne (Warszawa 1994).

Koole J.L., Isaiah III. Chapters 40-48 (HCOT; Kampen 1997). Małecki Z., Monoteizm w Księdze Deuteroizajasza (Iz 40-55) (Kraków 1998).

Melugin R.F., The Formation of Isaiah 40-55 (BZAW 141; Berlin - New York 1976)

North C.R., „The «Former Things» and the «New Things» in Deutero-Isaiah", Studies in the Old Testament Prophecy Presented to prof. T.H. Robinson (red. H.H. Rowley) (Edinburgh 1950) 111-126.

Oswalt J.N., The Book of Isaiah. Chapters 40-66 (NICOT; Grand Rapids, MI - Cambridge 1998).

Pikor W., „Izajaszowy Sługa Jahwe a nowe przymierze. Analiza kontekstualna Iz 42,1-9”, Zeszyty Naukowe KUL 49/2 (2006) 19-42.

Pikor W., Soteriologiczna metafora wody w Księdze Izajasza (Studia Biblica Lublinensia 4; Lublin 2009).

Ricoeur P., „Hermeneutyka świadectwa”, Nazwać Boga. Teksty Paula Ricoeura (tłum. R. Grzywacz) (Źródła Myśli Filozoficznej; Kraków 2011; oryg. franc. 1972) 15-46.

Simian-Yofre H., Sofferenza dell'uomo e silenzio di Dio nell'Antico Testamento e nella letteratura del Vicino Oriente Antico (Studia Biblica 2; Roma 2005).

Stachowiak L., Księga Izajasza 40-66. Wstęp - Przekład z oryginału - Komentarz - Ekskursy (PŚST 9/1; Poznań 1996). 
Westermann C., Isaiah 40-66. A Commentary (OTL; London ${ }^{9} 1996$; oryg. niem. 1966)

Zimmerli W., ,Io sono Jahvé”, Rivelazione di Dio. Una teologia dell'Antico Testamento (Milano 1975; oryg. niem. 1963) $18-44$.

Ks. Wojciech Pikor

Plac Mariacki 7

83-130 Pelplin

pikorwo@wp.pl

Ks. WoJciech PIKor, kapłan diecezji pelplińskiej, profesor zwyczajny nauk teologicznych, wykładowca na Wydziale Teologicznym UMK w Toruniu, rektor WSD w Pelplinie, członek Zarządu Stowarzyszenia Biblistów Polskich, moderator diecezjalny Dzieła Biblijnego im. Jana Pawła II. Opublikował m.in. książki Soteriologiczna metafora wody w Księdze Izajasza (Lublin 2009); Rola ziemi Izraela w przymierzu Boga z Izraelem. Studium historyczno-teologiczne Księgi Ezechiela (Lublin 2013); Odkrywanie siebie $w$ dialogu z Jezusem. Narracyjna lektura Ewangelii wg św. Jana (Pelplin 2014). 